
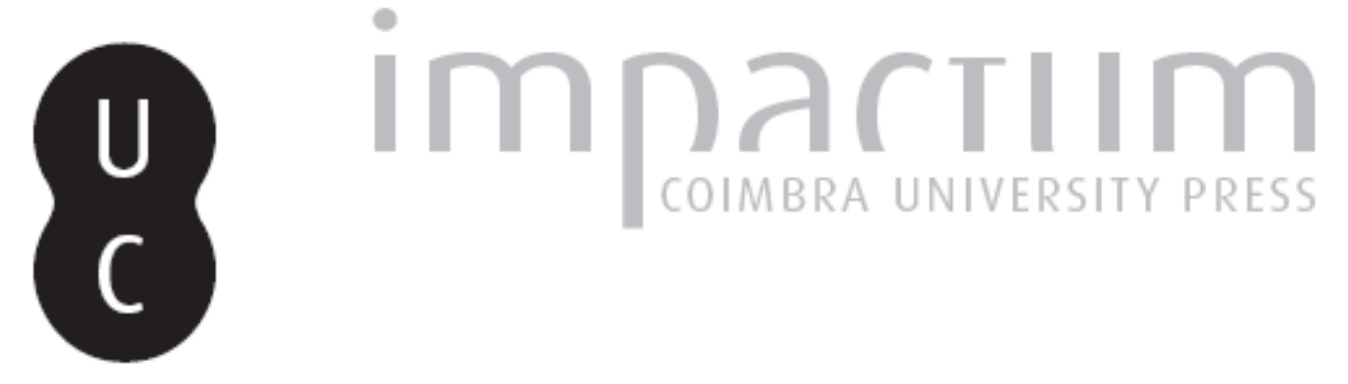

\title{
Fluidos corporais: matéria, fantasma e símbolo: uma nota de leitura sobre alguns livros recentes
}

Autor(es): $\quad$ Carvalho, Claúdio Alexandre $\begin{array}{ll}\text { Publicado por: } & \text { Faculdade de Letras da Universidade de Coimbra, Instituto de Estudos } \\ \text { Filosóficos }\end{array}$

URL

persistente:

DOI: $\quad$ DOI:http://dx.doi.org/10.14195/0872-0851_33_12

Accessed : $\quad$ 26-Apr-2023 14:20:42

A navegação consulta e descarregamento dos títulos inseridos nas Bibliotecas Digitais UC Digitalis, UC Pombalina e UC Impactum, pressupõem a aceitação plena e sem reservas dos Termos e Condições de Uso destas Bibliotecas Digitais, disponíveis em https://digitalis.uc.pt/pt-pt/termos.

Conforme exposto nos referidos Termos e Condições de Uso, o descarregamento de títulos de acesso restrito requer uma licença válida de autorização devendo o utilizador aceder ao(s) documento(s) a partir de um endereço de IP da instituição detentora da supramencionada licença.

Ao utilizador é apenas permitido o descarregamento para uso pessoal, pelo que o emprego do(s) título(s) descarregado(s) para outro fim, designadamente comercial, carece de autorização do respetivo autor ou editor da obra.

Na medida em que todas as obras da UC Digitalis se encontram protegidas pelo Código do Direito de Autor e Direitos Conexos e demais legislação aplicável, toda a cópia, parcial ou total, deste documento, nos casos em que é legalmente admitida, deverá conter ou fazer-se acompanhar por este aviso.

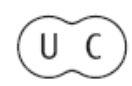




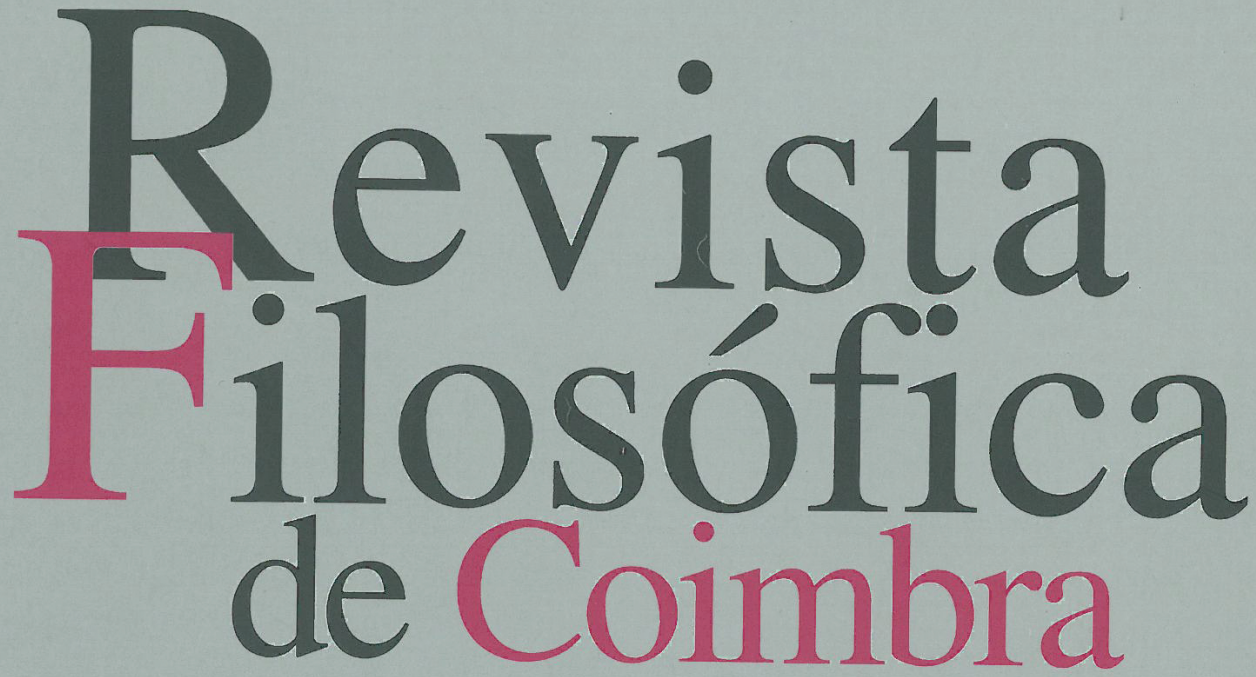

vol.17| n. .33 | 2008

Mário Santiago de Carvalho Fernanda Bernardo Luís António Umbelino Jean-Christophe Goddard Rui Alexandre Grácio Artur Ramos Luís M. Augusto Maria Luísa Portocarrero Jérôme Porée Diogo Ferrer Cláudio Alexandre Carvalho 


\title{
FLUIDOS CORPORAIS - MATÉRIA, FANTASMA E SÍMBOLO. UMA NOTA DE LEITURA SOBRE ALGUNS LIVROS RECENTES
}

\author{
CLAÚDIO ALEXANDRE CARVALHO \\ (Universidade de Coimbra)
}

\begin{abstract}
«Gender is a human invention, like language, kinship, religion, and technology; like them, gender organizes human social life in culturally patterned ways. Gender organizes social relations in everyday life as well as in the major social structures, such as social class and the hierarchies of bureaucratic organization»

(J. Lorber 1994: 6).
\end{abstract}

«sperm is a "liminal substance" that traffics between biological and social worlds.

That is, sperm is both a material and a symbolic entity, is a part of both nature and culture, and has scientific and social value.»

(L. J. Moore 2007:

Resumo: O estudo que agora se apresenta tem o propósito de submeter a apreciação crítica os mais recentes desenvolvimentos da linha de investigação iniciada por Judith Lorber. Partindo de uma apresentação dos pontos fulcrais dos trabalhos desta socióloga, pretendo deter-me na obra da sua colaboradora Lisa Jean Moore dando a ver como nesta se chegam a vencer algumas barreiras que o Construtivismo social impôs a si mesmo. Indo ao âmago caracterizador de macho e da fêmea, os fluidos corporais, esta autora pretende compreender o modo como os recentes avanços nas "biociências", bem como as suas repercussões e distorções em diferentes esferas da sociedade, estiveram na origem da alteração da ordem social fundada no género e no parentesco.

Creio ser oportuno tecer aqui algumas considerações relativas à inserção disciplinar deste estudo, não pretendendo no entanto um tratamento exaustivo das problemáticas. Deve qualificar-se como sendo no mínimo incompreensível a demissão do discurso filosófico do tratamento do conceito de família, não só porque este se manteve presente ao longo da sua história (desde a sua tematização inicial em Platão e Aristóteles), mas porque este continua ser hoje pertinente para 
uma compreensão das relações fundamentais da dependência humana. A Filosofia recolhe informação do tratamento descritivo próprio do discurso sociológico (e de outras ciências sociais quando tal for pertinente) relativamente ao género e à sexualidade na medida em que pretenda reconfigurar os seus conceitos precisamente a partir do terreno onde os seus pressupostos naturalizados não têm já capacidade significativa. Face a essa ubiquidade desprendida das múltiplas formas de reprodução de sentido na sociedade moderna, tenho como instrutivos os trabalhos das sociólogas que agora apresento, onde estão patentes antes de mais as possibilidades práticas de indivíduos (e o seu comportamento selectivo) a partir das quais se reconfigura a ordem normativa "exterior" e se estabelece o reconhecimento de novas formas de construção subjectiva. Uma abordagem séria destas relações requer uma atenção para o modo como na sociedade moderna os modelos prévios de parentesco deixaram de poder conter formas de intimidade, decorrentes elas mesmas de uma maior autonomia mas também do reconhecimento da individualidade livre de constrangimentos normativos apartados da sua construção temporal. É nas complexas mutações da estrutura e semântica social a que aqui se alude que surge a simples possibilidade de questionar o carácter natural do género. É a partir de uma análise da evolução histórico-social da semântica que é possível observar um sujeito que já não se subordina necessariamente a ordens identificatórias e autoridades previamente constituídas, e cujo projecto moderno tende para a constituição de uma autenticidade plena. É precisamente neste plano que a filosofia pode hoje pensar a identidade, a intimidade e o género.

O parentesco entendido como conjunto de relações onde se reproduz a vida e em que onde ocorre o trabalho de luto, tem assim de defrontar-se entre outras com questões biomédicas, não só nos aspectos relacionados com a prestação e administração de cuidados médicos, mas também devido ao impacto das novas tecnologias reprodutivas no seu seio.

\section{O trajecto teórico de Judith Lorber.}

Depois da publicação do influente e difundido Paradoxes of Gender em 1994, J. Lorber em colaboração com L. J. Moore, dedica em Gender and the Social Construction of Illness, uma especial atenção à presença do género enquanto variável significativa dentro da Biomedicina. Dando continuidade a essa incursão na investigação e aplicação de cuidados de saúde, em Sperm Counts, o seu mais recente trabalho, L. J. Moore sublinha mormente «o poder das ciências para naturalizar as relações sociais dada a sua posição privilegiada para fornecer um saber "oficial" base da compreensão do género e sexualidade.» (L. J. Moore 2007: 13). A ordem simbólica foi abalada, não apenas por intermédio de complexas recombinações discursivas presidindo às práticas individuais, mas principalmente no que resulta da confrontação com a virtualidade inerente ao biológico, 
sempre dependente de uma imensa variedade de factores de ordem social que condicionam a sua leitura.

Ao acentuar a multiplicidade inerente à promulgada divisão entre sexo (facto biológico) e género (construção sócio-cultural), Lorber ia no mesmo sentido do movimento que então ia ganhando expressão e densidade, patente entre outras, nas obras da psicóloga Sandra Bem ${ }^{1}$, do sociólogo Robert Connell ${ }^{2}$ e da filósofa Judith Butler ${ }^{3}$. A intersecção dos diferentes campos disciplinares promovida por estes autores vinha, em conformidade com o que se designou por Construtivismo social, desacreditar as mais arraigadas teses do "essencialismo biológico".

${ }^{1}$ A partir das suas pesquisas iniciadas em meados da década de 70, em especial o exame dos seus questionários quanto à androginia, o "Bem Sex Role Inventory" (BSRI) Cf. e.g. Idem (1974), "The measurement of psychological androgyny", Journal of Personality and Social Psychology, vol. 42, 155-162, Bem sublinha como as possibilidades de diferenciação de género estão condicionadas por expectativas dissimétricas relativas aos papéis de feminino e masculino, ainda que um mesmo indivíduo alterne frequentemente entre estes dois pólos. O conceito figurativo de "lentes do género" refere a interposição do simbólico, consolidado por um vasto conjunto de dispositivos discursivos, que funda a compreensão de si e dos outros sempre a partir de expectativas normativas quanto aos lugares polarizados do masculino e do feminino. Cf. Idem (1993), The Lenses of Gender. Transforming the Debate about Sexual Inequality, New Haven and London: Yale University Press.

2 Trabalhando o conceito de "masculinidade hegemónica", expõe a forma como a ordem e experiência de género estão agregadas nas normas de interacção quotidiana. Como força decisiva para a manutenção da ordem Connell destaca sobretudo o fenómeno de investimento catéxico, processo pelo qual o sujeito deseja o outro e se auto-identifica como objecto do desejo deste. Cf. Idem (1987), Gender and Power: Society, the Person and Sexual Politics, Stanford: Stanford University Press. No caso do género masculino não há um referente claro que permita circunscrever uma essência, a masculinidade é sim a inserção numa estrutura que tem diferentes níveis. Cf. Idem (1995), Masculinities, Berkeley: University of California Press.

${ }^{3}$ Destaca como estrutura de género está delimitada na complexa textura heterogénea de práticas discursivas. Desde Gender Trouble trata-se para Butler de retirar as consequências filosóficas resultantes da alteração da perspectiva epistemológica subjacente à abordagem da identidade de género. Esta deixa de ser pensada a partir do domínio do ser, nas múltiplas variantes filosóficas da identidade como resultante da emanação de uma essência, para ser pensada como construção performativa resultante da interacção, onde permanecem sempre possibilidades de reconfiguração do plano normativo. Neste âmbito deve ser salientado o conceito de "doing gender" resultante do trabalho desenvolvido por parte de Candace West e Don Zimmerman os quais afirmam: «a person's gender is not simply an aspect of what one is, but, more fundamentally, it is something that one does, and does recurrently, in interaction with others», Idem (1987), "Doing Gender", Gender and Society vol. 1, no. 2, 125-151, p. 140. 
Mas ao sustentarem o projecto programático de um jogo performativo sem fronteiras, capaz de subverter as políticas da identidade partindo do reposicionamento do corpo do psiquismo como construção temporal múltipla e fluida, estes autores tendiam a apagar a encruzilhada traumática, o "trouble" patente na obra de J. Butler, onde se inscreve a própria sexualidade e que toda a reconstrução do género tende efectivamente a "resolver". Desta forma deixavam por responder se há de facto um nódulo último da identidade de género inscrito no real. Ao excluir este íntimo anterior à simbolização ou ao ladear a sua tematização estes autores eram forçados a situar todo o indivíduo como estando já sempre marcado pelo simbólico, nunca excluído do seu espaço, sendo esta inserção impeditiva de uma deriva psicótica do sujeito. E a partir deste imbróglio, no qual as dimensões comunicativa (plano discursivo e actancial) e material (plano do corpóreo) revelam a sua impossível coincidência, que em Sperm Counts Moore, de forma talvez inesperada pela própria, abre caminho a uma reconfiguração do imaginário social motivada pela "verdade" da matéria.

Os recentes avanços nas técnicas reprodutivas confrontam-nos não só com a virtualidade da construção social do biológico, ou seja, a redução da contingência envolvida por recurso a processos selectivos, mas também com a autonomia e resistência do simbólico que se reconfigura na necessidade de resignificar o material. No domínio das biotecnologias, na impossibilidade de "ver" para lá da densidade dos nossos medos e fantasias, o desafio ético passa por uma "observação" capaz de ir além do horizonte de sentido actual sendo que a "bioética" não pode simplesmente apaziguar as possibilidades de recodificação remetendo para condições de inteligibilidade ou comunicação previamente estabelecidas. Este tipo de recurso a uma ordem ética prévia torna o discurso filosófico frequentemente tributário de uma compreensão da reprodução da cultura onde processos comunicativos, psíquicos e biológicos são considerados não a partir dos seus efectivos modos de instituição simbólica, mas de uma essência que aquele mesmo discurso deve ser capaz de tematizar recorrendo a variantes actualizadas da teoria da processão divina cúmplice de pressões sociais reaccionárias.

Em contracorrente relativamente às intuições da biologia mais ingénua, Lorber acentuava de modo certeiro como é a diferença de género, enquanto categoria social, que denota a constituição anatómica ${ }^{4}$. A sua investigação respondia às origens da instituição da subordinação da

${ }^{4}$ «Gender is so pervasive that in our society we assume it is bred into our genes. Most people find it hard to believe that gender is constantly created and re-created out of human interaction, out of social life, and is the texture and order of that social life»Idem, 1994: 13. 
"mulher" e da descriminação de grupos sexuais minoritários, nas suas múltiplas sobrevivências e manifestações nas sociedades funcionalmente diferenciadas. Partindo de formulações teóricas patentes em Foucault e Gramsci, mostrava esta autora como a única forma de vencer a ideologia, entendida como processo de manter invisível e virtualmente impensáveis as possibilidades patentes mesmo no simbólico formador das expectativas sociais, era expor as práticas pelas quais em diferentes sistemas se reproduz e consolida a hegemonia (Lorber 1994: 26). De modo a desmantelar o instituído era então necessária uma "mostração" das formas como a configuração binária "normativiza" a complexa e ínfima variabilidade histórico-cultural das construções relativas ao sexo, à orientação sexual, ao gerar de laços afectivos e às práticas sexuais.

Lorber enaltecia as várias formas como a "política da identidade", sempre culturalmente situada, molda o significado de corpo, orientação sexual e práticas sociais. Mostrava como numa dada sociedade um mesmo comportamento pode ser alvo de incentivo e tornado compulsório ou reprovado e reprimido, consoante a posição de um indivíduo no plano do simbólico. Já nos momentos de suspensão da ordem social, momentos em que o simbólico é posto a descoberto pelo "inantecipavel", aflora assombroso o carácter artificial das prescrições relativas aos papéis género. Lorber enaltece, entre outros, o caso da guerra onde é possível a mulher "transvestir-se" adoptando posições bélicas ou assumindo papéis masculinos admissíveis no estado de sítio. Mas ao entrar de novo em vigor a Lei do Pai e seus modos de jurisdição tais práticas são proscritas e repostas as expectativas tradicionais (e.g. 23-4; 63).

A tendência para reproduzir a diferença de género adquire extremos caricaturais quando a visibilidade é o meio comunicacional. Aí, a informação consabida pode traduzir-se em expressão inequívoca. Em 1994 Lorber apresentava o fenómeno desportivo e a regulamentação de algumas modalidades olímpicas como caso paradigmático do reforço dos padrões de género por recurso a ideais preconcebidos quanto à fisiologia e capacidade atlética, algo que a produção televisiva replica visualmente, investindo o movimento dos corpos de significações que contrastam a força muscular à beleza e graciosidade (pp. 41-3). Mas ainda que uma tal propensão para contrastar os caracteres corporais se continue a verificar, em especial em certas modalidades da ginástica, há também uma evidente tendência inversa que conduz à uniformização das práticas desportivas motivada justamente pelas exigências de performance inerentes a cada modalidade.

Em Paradoxos do Género a "disforia de género" e a transexualidade ao porem em causa o binarismo na sua fundação biológica, não deixavam de ser considerados como formas que ficam aquém do postular peremptório da fluidez da identidade. Refere J. Lorber que: «as fronteiras de 
género são preservadas quando os transexuais criam autobiografias coerentes sobre como sempre se sentiram assim» (p. 27). Em qualquer caso, com modos diferenciados de incidência, bissexuais, transexuais e travestis contribuem para a suspensão da normatividade sexual e genérica pensada como estando sustentada numa ordem pré-determinada das coisas (e.g., p. 95 et seq.).

Perante a constatação de que a arreigada «crença de que as divisões do género são normais e naturais persiste como o retrato subjacente à vida moderna.» ${ }^{5}$, nos ensaios posteriores a Paradoxes of Gender, numa vertente ora contestatária ora doutrinal, vêm esboçar-se novos contornos teóricos. A defesa de movimentos disruptivos, em que a identidade de género perde significado e as suas fronteiras não são mais reforçadas, tem o seu culminar no texto de 2005 Breaking the Bowls: Degendering and Feminist Change. Transita-se de uma tentativa de alteração das desigualdades presentificadas nos modos de interacção, para a necessidade de abolir as fronteiras de género subjacentes à génese e manutenção daquelas interacções constitutivas da identidade ${ }^{6}$.

Tendo em conta este movimento de "de-generação", o texto dedicado aos cuidados de saúde e ao carácter socialmente construído da doença afigura-se como um momento de charneira marcado por uma postura mais comedida, requerida ela mesma pela vertente pragmática do trabalho. Texto onde a diferença genérica é pensada como potenciadora de equilíbrios quando submetida a mecanismos de auto-regulação adequados. As autoras sublinham sobretudo como a auto-observação do sistema de saúde requer uma sensibilidade apurada para o factor género e a sua constante interconexão com outros factores estratificatórios.

\section{O Género e a administração da Saúde}

Nesse trabalho reeditado em 2002 intitulado Gender and the Social Construction of Illness ${ }^{7}$, agora em co-autoria com Lisa Jean Moore, Judith

5 Idem (2000), "Using Gender to Undo Gender: A Feminist Degendering Movement", Feminist Theory, vol. 1, no. 1, 2000, pp. 79-95, p. 80.

${ }^{6}$ Nessa sua última obra afirma a socióloga que: «it is only by undercutting the gender system of legal statuses, bureaucratic categories, and official and private allocation of tasks and roles that gender equality can be permanently achieved.» (Idem (2005), Ibidem, New York: Norton, p. 164).

${ }^{7}$ A primeira edição deste texto data de 1997 e tem Judith Lorber por autora exclusiva. Na versão em co-autoria, os capítulos da edição anterior são sujeitos a revisão e actualização, procedendo-se também à inclusão na constelação de temas analisados, de uma abordagem das Incapacidades e da cirurgia genital. 
Lorber apresentava os resultados de uma investigação que atendia não só ao desafio de uma leitura da doença a partir de uma análise de género, mas também à pertinente formulação de uma teoria relativa à forma como o género tem a potencialidade de moldar a prática de cuidados médicos. Dentro da economia do pensamento de Lorber este é um texto que se pode dizer conservador na medida em que permanece cingido a uma política da identidade, há um reconhecimento tácito de que esta é imprescindível para a implementação de mudanças efectivas no que respeita às desigualdades de género na saúde. A visão panorâmica que Lorber apresentava na obra de 1994 tem aqui uma continuação na qual, acompanhando uma focagem mais precisa, são mobilizadas a generalidade das convicções teóricas respeitantes ao género como estrutura normativa diferenciadora e geradora de desigualdades. A vários níveis as autoras incidem na necessidade de um "calibrar" do sistema de saúde tornando-o selectivo face a factores de género, de modo a impedir que nos seus processos ele seja propiciador de reprodução de exclusões "cegas". Detendo-se sobretudo nas peculiaridades da institucionalização dos cuidados de saúde em solo norte-americano e confinando-se predominantemente às doenças do foro "fisiológico", as autoras salientam como um largo conjunto de processos interiores e envolventes ao que se designou por "biomedicina" não podem ser tidos como imunes a um vasto espectro de factores sociais de índole estratificatória normalmente tidos por acessórios: raça, estrato social, cultura e idade. É pois na medida em que o género se apresenta estritamente entrelaçado com estes factores determinantes da hierarquia do poder e distribuição de recursos económicos, que ele pode ser então tomado como horizonte privilegiado para compreender aquilo que as autoras agregam sob a formulação "construção social da doença". Num primeiro plano trata-se de atentar nas implicações de género, raça, etnicidade e cultura constatando-se a forma como estes factores são largamente causadores dos diferentes doenças e sintomas. A partir deste momento inicial procura-se examinar a forma como os factores sociais intervêm na construção do "corpo do saber" quanto à doença, sendo daqui que resulta a necessidade de uma nova atenção à construção do género em prol de uma concepção capaz de saúde pública.

A perspectiva de Lorber e Moore tem o seu eixo motriz na noção algo vaga de um "cuidado feminista na saúde", cuja real tradução no sistema de saúde redunda em grande medida nas aplicações já adiantadas a partir de outros domínios das ciências sociais ${ }^{8}$, os quais apostam sobretudo na

${ }^{8}$ É nomeadamente o caso de perspectivas éticas onde se enaltece a necessidade premente de suspender o "agir eficiente" próprio de técnicos paternalistas, humanizando a relação clínica a partir do seu carácter intersubjectivo, tendo em atenção a particularidade 
necessidade de formação de profissionais de saúde mais sensíveis aos aspectos "não técnicos" da relação médica9 . Neste âmbito, de modo a favorecer o eclodir de um novo paradigma, Lorber e Moore avançam diversas propostas para a transformação nas estruturas de financiamento, treino e prestação de cuidados biomédicos. Apesar da fragilidade deste seu aspecto programático, o tipo de abordagem adoptado permite escapar a uma compreensão redutora da geração de desigualdades e implicações da identidade de género, numa área tão delicada como a saúde.

Obliterando a evidente relatividade cultural inerente a qualquer sistematização nosológica, bem como o facto de que a doença é sempre uma experiência vivida num contexto social, destacadas correntes da medicina definiam até bem recentemente o conceito de doença, como um distúrbio fisiológico ao qual são estranhas causas ou tratamento de ordem social (p. 2). Defendem as autoras que dentre todos os factores culturais, o género é o principal responsável pela transformação do "corpo físico" (fisionómico, biológico e genético) em "corpo social" originando dois grupos de indivíduos claramente diferenciados ao nível de comportamento, atitudes e emoções. A ordem social nos diferentes sistemas parciais (economia, família, religião, arte, política e direito) reproduz e mantém a diferença de género, sendo que o seu binarismo serve de base à significação retrospectiva nos diferentes níveis (organizacional, relacional e individual) estabelecendo distintos padrões de expectativas e oportunidades de vida. É desta forma que processos biológicos são sempre traduzidos em vivência social "naturalizando" a diferença de género. Esta vê-se consolidada nas diferentes práticas adstritas a cada uma das posições simbólicas. Geram-se assim diferenciações claras em domínios tão diversos como o desporto, as práticas alimentares e o trabalho. Os fenómenos de saúde e doença envolvem invariavelmente a transformação do corpo e do psiquismo por intermédio de práticas sociais, algo que se inicia antes ainda do nascimento afectando «feto, bebé e criança tão profundamente quanto a herança genética» (p. 6).

Passo agora em revista alguns dos tópicos abordados pelas autoras de modo a enaltecer os domínios em que é fulcral que uma perspectiva de género complemente abordagens biológicas, genéticas, culturais e éticas, e informe a implementação de políticas e a organização de práticas de saúde pública.

\footnotetext{
do paciente. Cf. sobretudo Lorber \& Moore 2002: 143-48. Doravante todas as referências a paginação ínsitas no texto são relativas a esta obra.

9 «Porque a base do saber da medicina moderna está baseada nas ciências (biologia, bioquímica, fisiologia, endocrinologia, e daqui em diante), os aspectos sociais e ambientais têm menos atenção no treino e prática médica.» (p. 138).
} 
Partindo de uma ideia de "epidemologia social" e apoiadas em dados estatísticos as autoras mostram como diferentes grupos sociais estão expostos a diferentes causas e por conseguinte a diferentes tipos de incidências de sintomas e doenças. Esta tónica serve de ocasião para pôr em causa a categorização que preside à interpretação dos dados estatísticos que determinam prioridades políticas (pp. 33-35). As diferentes frequências de esperança média de vida, a causa de morte e doenças ao longo da vida são os reflexos de dissimetrias no estatuto social de homens e mulheres, de diferentes condições económicas e da institucionalização social do racismo.

Além destes fenómenos sócio-culturais de exclusão, na sua análise crítica as sociólogas evidenciam também como uma ténue delimitação normativa da esfera da saúde relativamente ao mercado económico dá azo a perversões de diversa ordem. Por pressões exteriores ao sistema da saúde (entendido este no sentido estrito enquanto conjunto de instituições e práticas centradas no cuidado das debilidades psicofisiológicas), resultantes em especial da inserção da indústria farmacêutica no mercado económico, foi-se gerando a "medicamentalização" do mais diverso tipo de sintomas frequentemente inofensivos. Tal tendência para automatizar a relação causal entre a detecção de sintomas e a produção de fármacos é contestada por Lorber e Moore como forma de, muitas das vezes com o aval ou mesmo o incentivo de programas estatais, recalcar aquilo que são causas sociais endémicas (como é o caso dos diversos factores de exclusão, a pobreza e a poluição) que toda a política em prol da saúde pública deve aplacar por intermédio de medidas preventivas. A denúncia incide igualmente no facto de serem os mercados em expansão -como os dos antidepressivos, dos anti-alergicos, ou do tratamento da disfunção eréctil - a determinarem exclusivamente as linhas de investigação prioritárias. Verifica-se, como consequência imediata, o consumo de preciosos recursos imprescindíveis para áreas biomédicas que uma lógica estritamente económica consideraria secundárias. No caso dos EUA, esta mesma dependência face ao sistema económico gera, para uma larga margem da população, a deterioração da relação clínica e da prestação de cuidados médicos, fenómenos que vão a par do progressivo desprestigio da outrora reverenciada figura do médico ${ }^{10}$.

${ }^{10}$ As autoras apontam a mediação das seguradoras entre utente e instituições de cuidados médicos como as principais responsáveis pelo cercear de custos que frequentemente resulta no decréscimo da qualidade dos cuidados na saúde (Cf. pp. 8-9). Actualmente será difícil encontrar documento mais expressivo das perversões geradas ao longo da progressiva privatização do sistema de saúde norte-americano do que o mais recente documentário de Michael Moore: Sicko, 2007. 
Outro tema pertinente numa discussão sobre saúde é a própria divisão médica do trabalho. Lorber e Moore atentam no modo como os papéis de género têm clara repercussão na implementação dos cuidados médicos e expectativas quanto ao trato com os pacientes permanentemente incapacitados (pp. 58-60). Um conjunto de significativas alterações, impulsionadas sobretudo pela crescente presença de mulheres em todas as áreas da biomedicina, propiciou o irromper de novos modos de estruturação dos cuidados de saúde bem como uma maior sensibilidade para as especificidades da saúde feminina. Mas se para os profissionais de saúde esta diferenciação pode ter a virtude de promover a exploração de capacidades comunicacionais, referem as autoras que ela não deixa de se repercutir em hierarquizações perniciosas: «o efeito latente entre os agentes de saúde é ainda assim o reforçar da estratificação de género, com as mulheres remetidas para o contacto directo, manual e cuidados primários, e os homens em prestigiosas e poderosas posições de deliberação política.» (p. 51).

Outra controversa questão levada a escrutínio por estas sociólogas é a construção médica e social dos fenómenos da tensão pré-menstrual (TMP) e da menopausa. Se em determinadas culturas primitivas estas alterações inerentes à maturação orgânica dos indivíduos do sexo feminino serviam como indicação para a alteração de estatuto social (pp. 75-6), na sociedade contemporânea encontramos aqui a medicamentalização e o seu poder para diagnosticar como doença o que - salvo quadros clínicos excepcionais- são sintomas difusos ${ }^{11}$. Uma das consequências nefastas da vulgarização deste diagnóstico peremptório é uma revalidação de crenças ancestrais que tomam estes processos fisiológicos como signos inequívocos da incapacidade de controlo do corpo e das emoções, sendo que a consequência social é a revalidação da convicção de que as mulheres não são aptas ou fiáveis, não sendo recomendável a sua designação para posições de chefia ou tarefas envolvendo altos nível de responsabilidade ou stress.

A "geração de corpos", no sentido mais literal do termo, seria sempre uma questão incontornável especialmente num tema tão caro a Lorber como o da inserção simbólica dos intersexuais (sejam indivíduos hermafroditas, nascidos com características anatómicas de ambos os sexos

${ }^{11}$ Lorber e Moore apontam para o excesso de medicação, também em casos de insónia, desinteresse sexual e prevenção da osteoporose, quando na verdade para todos estes sintomas as respostas mais adequadas, porque não envolvendo riscos graves de saúde e efeitos secundários verificados em alguns tratamentos, situam-se no exterior da medicina convencional e por conseguinte longe dos interesses económicos das grandes empresas farmacêuticas (p. 88). 
medicamente considerados, ou com ambiguidade genital). Neste tópico debatem-se portanto as cirurgias genitais, não só a delicada questão dos rituais religiosos de mutilação genital cujo poder identificatório certas culturas insistem em manter bem vivo ${ }^{12}$, mas também as intervenções cirúrgicas em intersexuais. Nestes indivíduos, além da aptidão anatómica e questões estéticas, o que está em causa é saber que critério pode presidir à opção de acentuar traços "pénianos" ou "clítorianos"13 por via de uma cirurgia de "clarificação". Lorber e Moore destacam a retórica médica envolvida nestes casos: «a mensagem dos médicos para os pais é a de que a criança tem um sexo verdadeiro, que é macho ou fêmea, e que a cirurgia é necessária de modo a fazer com que os genitais anómalos correspondam ao verdadeiro sexo ${ }^{14}$. Mas na verdade, o sexo é uma ficção social (...)» (p. 102). No caso dos indivíduos intersexuais o sexo acaba por ser "outorgado" de acordo com as várias normas de socialização, a partir das quais, independentemente da genitália, se estabelecem as ínfimas possibilidades combinatórias da construção biográfica. Foi reclamando prazeres desconhecidos ao simbólico que surgiram movimentos civis que censuram a prática da "clarificação". Esta toma invariavelmente por guia uma ficção do normal que, na sua resolução, além de afinal proteger o indivíduo da chacota e curiosidade alheias, consolida «operações de controlo social que perpetuam as condições da conformidade do género.» (p. 104).

$\mathrm{O}$ destaque que as autoras concedem à abordagem da SIDA, é inteiramente justificado porquanto dentre as múltiplas doenças, é nesta que, também devido à sua breve e densa história, se mesclam a descriminação e o estigma face à sexualidade, ao género, à raça e ao estrato social. Os diversos discursos que se dispõem em seu torno «são exemplo primeiro da forma como a doença reflecte visões culturais de mulheres e homens, homosexuais e heterosexuais, pobres e ricos, gente de cor e brancos, "estrangeiros" e "nativos".»( p. 11). Poder-se-ia dizer que além do seu

12 A prática da "excisão feminina" apesar de estar sob ataque cerrado por parte de várias organizações de direitos humanos continua a ser praticada em várias regiões do continente africano. (pp. 94-6).

${ }^{13}$ Lisa Jean Moore tinha já participado num trabalho onde tomando por material de análise manuais de anatomia, se constatava que foi sob os auspícios do movimento feminista que foi possível pela primeira vez ter uma percepção anatómica do clítoris. Cf. "Inscribing Bodies, Inscribing the Future: Gender, Sex and Reproduction in Outer Space", Sociological Perspectives. vol. 38, no. 2, Summer 1995, pp. 311-333.

${ }^{14}$ Políticas que de acordo com Sandra Bem assentam em «assumpções acríticas de que eles [intersexuais] são anomalias que requerem correcção hormonal e cirúrgica.» Idem (1995), "Dismantling Gender Polarization and Compulsory Heterosexuality: Should We Turn the Volume Down or Up?" Journal of Sex Research. vol. 32 no. 4, 329-334, p. 333. 
aspecto traumático, impossível de significar plenamente, marcado pelo súbito início de uma degradação física implacável, aquilo que prevalece na SIDA é a estrutura social e o imaginário prévios ao seu irromper. Neste sentido, as autoras afirmam que esta é uma doença transmitida não apenas pelos fluidos corporais (sémen, sangue e leite) mas também pela própria "relação social", sendo que: "diferentes estatutos sociais posicionam pessoas em diferentes níveis de risco e em diferentes condições de acesso a cuidados médicos.» (p. 131). Em diversos sistemas de saúde terá sido a convicção de que a doença progredia de acordo com uma ordenação divina -que viria finalmente validar a patologização da homosexualidade, bem como as presunções moralistas que impunham divisões naturais entre gays e heterossexuais, entre prostitutas e esposas, entre toxicodependentes e "limpos"- a determinar a inacção institucional manifesta no negligenciar de medidas relativamente a grupos que se julgou estarem abrigados da "praga", mas também a passividade na protecção de grupos facilmente circunscritos como no caso consumidores de drogas intravenosas.

A inércia psíquica do "homem médio" persevera na segurança de categorias sociais estanques e incomunicáveis onde se naturalizam as posições do masculino e do feminino, dos promíscuos e dos "verticais", dos ricos e dos pobres. Mas a transmissão da doença, tendo por veículo de contágio o elemento líquido, torna visível uma ordem fluida de trocas constitutivas do simbólico e actuantes na "liquefacção" da sua solidez, e que de outra forma permaneceriam ocultas sob o manto dos estereótipos.

Pese embora manterem-se dentro dos estritos limites de uma investigação empírico-analítica, as autoras conseguem um tratamento sintético dos entrelaçamentos contingentes de género, raça e classe enquanto factores sociais geradores de desigualdades no acesso aos cuidados de saúde. O que resulta é sobretudo a necessidade de refractar o "corpo universal", referência ideal a partir da qual a diferença é rasurada e violentada, cindindo-o a partir das funções e disfunções decorrentes da sua envolvente sociocultural, em diversos "corpos sociais".

\section{Como (se) conta o esperma?}

Resultado de 15 anos de investigação académica e de vários "contactos" pessoais e profissionais com o sémen, os quais são frequentemente relatados na primeira pessoa (Moore, 200715: 155-67), Sperm

15 Doravante todas as referências a paginação ínsitas no texto são relativas a esta obra. 
Counts ${ }^{16}$ fornece uma compreensão abrangente das implicações que as diversas representações dos fluidos corporais têm na construção do género. A leitura plurifocalizada de Moore permite-lhe interpretar as diversas significações que o esperma, na sua fluidez característica, a que já aludimos, vem adquirindo nas sociedades ocidentais. $\mathrm{O}$ destaque de que o sémen é alvo dentre os diferentes fluidos corporais é consonante com o seu recente protagonismo, em especial a evolução das concepções e aplicações científicas desta substância contribuíram para que num período relativamente curto ele tivesse transitado «do domínio da segregação para o do quotidiano» (p. 10). Sendo notório o seu carácter histórica e culturalmente situado, ele é barómetro claro das diversas representações e concepções da masculinidade na ciência e medicina reprodutiva, na educação, na criminologia e justiça, mas também na prostituição e pornografia. Os tipos ideais reproduzidos em cada uma destas diferentes esferas requerem performance, instituindo e incitando a comportamentos de género. Diz Moore: «o acoplar da minha lente analítica ao esperma possibilita interessantes perspectivas sobre como o esperma "é gasto" e reabsorvido, mas também como ele nada, jorra, querena e embate por condutas, pénis, vaginas, tubos de ensaio, laboratórios, famílias e política.» (p. 11) Este elemento material -as múltiplas designações e propósitos que serve - permite agregar todos os campos em que se reconfigura permanentemente a identidade co-referencial dos géneros. As representações patentes no saber que cada sistema constitui relativamente a sémen e esperma, remetem de modo mais explícito para diferentes concepções quanto à própria masculinidade.

Continua a ser pertinente a constatação feita por parte de Emily Martin ${ }^{17}$, ainda no início da década de 90 , de que a distribuição dos papéis de género nas representações populares e artigos médicos permanece apegada às linhas mestras que presidem às considerações relativas aos sexos e à concepção que Aristóteles delineou na Geração dos Animais. Exemplo claro disso mesmo pode ser encontrado num domínio limítrofe às técnicas reprodutivas. Aí têm vindo a ser adiantadas diversas variantes da apelidada "teoria da competitividade" desenvolvida desde os finais dos anos 60 por Geoff Parker. A partir de regularidades no comportamento

16 Este título alude à significação múltipla da expressão "sperm counts" que primeiramente designa a prática biomédica de "contagem de esperma", mas além deste método para a aferição da potencialidade/fertilidade do esperma, remete também para a sua presença e importância crescentes aos mais diversos níveis da sociedade.

17 Idem, (1991) "The Egg and the Sperm: How Science Has Constructed a Romance Based on Stereotypical Male-Female Roles", Signs: Journal of Women in Culture and Society, vol. 16, no. 3, Spring 1991, 485-501. 
sexual de diversas espécies animais, este entomologista pensava poder estabelecer equivalências claras com comportamentos humanos de acasalamento. Parker avançava «ideias quanto a sexualidade, relacionamento e reprodução humanos», ideias estas inseridas numa teoria em que "projecções de comportamento, motivo e carácter fluem livremente entre espermatozóides e os homens que os produzem» (p. 31). Mais recentemente Baker e Bellis ${ }^{18}$, indo além daquela primeira formulação, defenderam a «competição de esperma» como força decisiva capaz de moldar a genética e pulsões sexuais humanas, recusando o acaso e salientando a capacidade estratégica de um sémen com organização diferenciada autónoma assemelhado a uma força militar moderna em que os espermatozóides tal como os militares têm funções estritamente definidas e patentes correspondentes. Tomando por base esta mesma teoria, viria também a ter considerável repercussão na comunidade científica a chamada "hipótese Kamikase", de acordo com a qual a maior parte dos espermatozóides não "aspiram" à fecundação mas "trabalham" em exclusivo para impedir o sucesso de um adversário. Os espermatozóides anteriormente tidos por excedentários, passaram de passageiros indesejáveis a membros de direito, mártires heróicos sacrificando-se pela sua comunidade de esperma (p. 34, et seq.). Esta imagética do polimorfismo do esperma não pode ser entendida apenas como método didáctico expositivo. Análoga a uma divisão social do trabalho, nela se concentram todos os tropos característicos de uma ideologia da "masculinidade hegemónica"19. Esta encenação bélica do saber científico consolida a ideia de que só o superior pode vencer e restaura a convicção de que é no sémen que encontramos a base pulsional e energética do homem. Em nome desta verdade, tem então de banir qualquer alusão não só ao "mau" esperma e à realidade da sua manipulação tecnológica, mas também a todas as formas de sexualidade não procriativa seja ela heterossexual ou homossexual.

Ainda nos anos 80, a filósofa e bióloga Donna Haraway notou ${ }^{20}$, especialmente a respeito do estudo do comportamento dos primatas como

18 Estes autores avançam como hipóteses centrais, a evolução de um comportamento adaptativo (inscrito geneticamente) no macho que tem por fim maximizar as probabilidades de assegurar descendência, e como complementar, a adaptação anatómica do pénis de modo a favorecer a expulsão de sémen de eventuais competidores. Cf. Idem (1995), Human sperm competition: Copulation, Masturbation, and Infidelity, London: Chapman and Hall.

${ }^{19}$ Robert Connell fixou a significação precisa deste conceito como «A configuração da prática do género que incorpora a resposta correntemente aceite para o problema da legitimação do patriarcado, que garante (ou se presume garantir) a posição dominante dos homens e a subordinação das mulheres». (Connell 1995: 77).

${ }^{20}$ Cf. Idem (1989), Primate Visions: Gender, Race and Nature in the World of Modern Science. New York \& London: Routledge. 
fonte de interpretação da organização social humana e da conduta dos seus indivíduos, a irresponsabilidade de tal cruzamento entre as constatações da ciência propriamente dita e a sua degenerescência em ciência popular (à qual são permeáveis certas correntes da Antropologia e Psicologia evolucionista). Esta prática é gratificante e apaziguadora para cientistas e leigos, na medida em que racionaliza de forma aparentemente naïf diversas formas de dominação social, estando a sua leitura mediada pela compreensão naturalizante da socialização de raça e género. Tem cabido a diferentes áreas académicas a tarefa de denunciar o facto de que este tipo de hipóteses podem ser consideradas relevantes para a compreensão do comportamento e organização social humana apenas no caso de estarem adequadamente suportadas por estudos em grupos humanos.

De qualquer modo aquele fascínio que leva ao exaltar do sémen, enaltecendo a sua perfeição e capacidade reprodutiva incólume a qualquer perturbação, conta com fortes resistências dentro da comunidade científica. Investigadores como o endocrinologista Richard Spark apontam para indicadores claros da diminuição da fertilidade ${ }^{21}$ nas contagens e avaliação de performance do esperma ${ }^{22}$. Moore enaltece como a «contagem de esperma declinante tem consequências para o corpo social bem como para os corpos individuais» (p. 26). A percentagem de incidência da infertilidade entre ambos os sexos é aproximadamente a mesma. Ainda que continue a afectar mais as mulheres (Lorber \& Moore 2002: 22), o estigma relacionado com o não cumprimento de expectativas sociais origina por vezes também nos homens humilhação, desespero e depressão extremos.

O discurso científico, sempre culturalmente situado, continua a reproduzir as posições simbólicas e hierarquia social na significação do material. O caso paradigmático a que Moore faz referência neste âmbito é à frequente caracterização do esperma "debilitado" por intermédio de advérbios femininos (p. 23).

${ }^{21}$ Cf. Idem (1988), The Infertile Male: The Clinician's Guide to Diagnosis and Treatment, New York: Plenum Medical Book Co. Entre os factores referidos estão a crescente contaminação ambiental (em especial o aumento exponencial de estrogénio), vários tipos de doenças infecciosas, entre as quais DST (doenças sexualmente transmissíveis), e certos comportamentos histórica e culturalmente associados à masculinidade (consumo de álcool, marijuana e tabaco), Cf. Moore 2007: 25.

22 Actualmente a análise de esperma vai bem além da simples contagem, podendo envolver inúmeros parâmetros de mensuração da qualidade do esperma, entre os quais os mais usuais são a avaliação da motilidade e morfologia (adicionalmente é possível aferir volume, viscosidade, $\mathrm{pH}$, densidade e viabilidade). 
A manipulação (o armazenamento ${ }^{23}$ e venda) e os processos de selecção (inúmeros testes para determinar qual o esperma mais apto e diversas técnicas para a selecção de traços genéticos) a que o sémen é actualmente submetido, são considerados por parte de L. J. Moore como uma ameaça sem precedentes à masculinidade. Não deixa de ser sintomático o facto de ser precisamente a partir da biomedicina reprodutiva, cujo domínio intelectual foi predominantemente masculino e cujos progressos tiveram primeiramente em vista a infertilidade do casal da família nuclear tradicional e ordem heterossexual assegurando-lhe a descendência biológica, que se pavimentaram novas vias para aquilo que foi um significativo crescimento de famílias autónomas ditas alternativas, como sejam mães solteiras por opção e casais de lésbicas ${ }^{24}$. O impacto das novas técnicas de reprodução ${ }^{25}$ exige um reconceptualizar da reprodução, da sexualidade, da família e da paternidade; sendo crucial o facto de que nos processos selectivos destas práticas concernentes ao núcleo da intimidade, a participação do homem se ter tornado potencialmente redundante. Os refúgios para a auto-representação de uma masculinidade reprimida são geralmente domínios onde se assiste à performance caricatural da virilidade: o desporto de massas e a pornografia. Apesar destas reminiscências, as quais tendem a ser integradas em diferentes canais comunicacionais independentemente da identidade de género, é inequívoco que nas sociedades modernas sujeitas à mediatização a produção da nova ordem de género e parentesco não está mais moldada de acordo com a masculinidade nostálgica onde diferente membros da casa, centro simbólico da reprodução da ordem patriarcal, estavam subordinados ao paterfamilias cujo dominium era pressuposto inquestionável.

Vejamos agora o modo como aqueles processos comunicativos científicos, sustentados em construções retóricas que reduzem os aconteci-

${ }^{23}$ Foram preponderantes os avanços tecnológicos da preservação em nitrogénio líquido. Além de permitir longa viabilidade de células e tecidos, dando assim resposta às eventuais exposições do organismo a ambientes que põem em risco a fertilidade, a crioperservação evoluiu ao ponto de ser integrável em cómodas transacções comerciais (pp. 96-7).

${ }^{24}$ Neste sentido afirma L. J. Moore: «As práticas científicas que elevam o esperma ao vedetismo de único actor reprodutivo também transformam num bem acessível com relativa facilidade.» (p. 43).

${ }^{25} \mathrm{Na}$ Procriação Medicamente Assistida (PMA), além da famosa FIV (fertilização in vitro) são de destacar as técnicas de Inseminação intra-uterina e intra-cervical, bem como a ICSI (injecção introcitoplasmática). As temáticas da investigação em células estaminais embrionárias (ES) e as possibilidades relativamente à clonagem reprodutiva humana não são alvo de reflexão por parte desta autora. Outra prática que carecia de uma maior atenção por parte de Moore seria, nas suas diferentes variantes, a procriação por substituição. 
mentos ao carácter positivo de facto, são amplificados noutras esferas da sociedade. Abordemos, seguindo de perto as pertinentes considerações tecidas por L. J. Moore a respeito da literatura infantil, da indústria sexual e do sistema criminal.

Moore procede à categorização e análise exaustivas de 27 de livros infantis dedicados à reprodução humana, cuja variedade é representativa do universo de obras agrupáveis nessa categoria, disponíveis no mercado norte-americano ao longo de um período de 50 anos, dirigidos a idades compreendidas entre os 4 e 12 anos (pp. 159-60). O eufemismo é nota constante (patente logo na denominação bastante usual destas obras como de "factos da vida"), e sem excepção as obras apresentam imagens idealizadas de família, sexualidade e criança. Nos livros infantis o esperma surge geralmente antropomorfizado, e apela-se à identificação com um dos personagens fulcrais ao enredo. Todos os tropos dos contos de fadas são afectados para estes cenários onde decorre a representação do espermatozóide. O espermatozóide é construído como «singular prince in shining armour who will save the day» (p. 46) ${ }^{26}$.

O esperma surge como extensão de um pai heróico envolvido numa relação heterossexual intencional e asséptica. É obturada qualquer inquietude inerente à actividade sexual (aqui reduzida à sua vertente genital), macho e fêmea são geralmente apresentados desnudos de desejo e problemas, envolvidos numa tarefa prática quotidiana que só casais férteis podem executar. O coito heterossexual é o ponto de apoio simbólico a partir do qual se tece a narrativa que recupera a força identificatória e proibitiva das posições de pai e mãe. É frequente fazer-se uso de um recurso engenhoso, no momento imediatamente anterior à cópula há uma metástase, no decurso da representação o evento é desincorporado e a personalidade e subjectividade dos progenitores é transferida para os seus respectivos gâmetas. Reavivando o longo período histórico em que o sémen era tido por único responsável pela reprodução ${ }^{27}$, a partir desse ponto o relevo é dado quase exclusivamente à jornada épica do esper-

${ }^{26}$ A este respeito Cf. Moore, L. J. (2003), "Billy, the Sad Sperm with No Tail: Representations of Sperm in Children's Books", Sexualities, vol. 6, no. 3-4, 279-305. e Idem (2005), "In Shining Armor: Representations of Sperm in Children's Books", American Sexuality Magazine, Vol. 3, no. 1: <http://nsrc.sfsu.edu/MagWebpage.cfm>

${ }^{27}$ Para além da obra de T. Laqueur cujo mérito principal consiste em fornecer de uma visão de conjunto sobre a transitoriedade histórico-cultural das construções da diferença sexual, Idem (1990), Making Sex: Body and Gender from the Greeks to Freud, Harvard University Press: Cambridge, remeto também para a bióloga e historiadora da ciência Clara Pinto Correia: Idem (1997) The Ovary of Eve: Eggs and Sperm and Preformation. Chicago: University of Chicago Press. (Trad. Port.: O Ovário de Eva, Lisboa: Relógio d’Água). 
matozóide em busca da ansiosa e frágil donzela (oócito). Em sintonia com os discursos teológico, filosófico, moral, e médico que remeteram recorrentemente a diferentes teorias dos homunculi, os espermatozóides são aqui retratados como tendo intencionalidade, autonomia e sentimentos (pp. 61-62). Também devido à faixa etária a que se destinam, os livros são abundantes em imagens que, além de sugerirem um isomorfismo representacional, são complementadas com terminologia científica certificando a credibilidade e veracidade - ausente de "contos de fadas" veiculados por canais tradicionais- de uma construção narrativa que continua a ter por referência aspectos simbólicos e expectativas sociais heteronormativas (por este termo entende-se aqui a utilização de ideais sociais e culturais ao serviço da reprodução do carácter inquestionado da naturalidade e superioridade da heterosexualidade). Assim enquanto o espermatozóide tem um discurso masculinizado e está coberto em vestimentas com força identificatória, o oócito é remetido a uma posição discreta, e, quando personificado, quase não fala sendo femininamente transvestido.

Moore nota que curiosamente são os livros que preconizam a doutrina cristã, aqueles que menos tendem à antropomorfização das substâncias reprodutivas e seus componentes, ou seja, não procedem à transferência da densidade emocional heterossexual de fundo para os gâmetas (p. 67). Oócito e espermatozóide são libertos do mandato humano e postos sob a vontade de Deus. Num acto de fé radical os autores destes livros optam, como que inspirados em Malebranche, por uma visão ocasionalista prescindindo da descrição dos ditos "factos" que originam a vida. A causa eficiente é subtraída aos processos biológicos, e a suposta isenção da descrição científica é substituída pela magia da concepção.

Na sua narrativa didáctica todos os livros infantis dedicados à apresentação da reprodução humana, tanto seculares como religiosos, acabam sempre por se exceder no seu propósito, reproduzindo «guias para o modo como as crianças devem entender género, orientação sexual, relacionamentos e cidadania.» (p. 68). Devemos ressalvar que, tendo em conta o público-alvo das edições, a simbolização é inevitável e mesmo desejável sob pena de negligenciar uma compreensão valorativa do fenómeno da sexualidade humana. Aquilo que Moore põe em causa é o facto de invariavelmente haver uma recriação de sistemas de crenças caducos quanto às formas de sexualidade, família e género que devem presidir à auto-compreensão da criança. É assim que Moore, escapando a uma regulação moral estrita, e liberta de perspectivas naturalizantes da cultura -as quais reduzem a sexualidade humana à sua vertente reprodutiva, monogâmica e heteronormativa- pode dar a entrever uma nova didáctica do esperma. De acordo com a autora, tal esperma não é o do amanhã, mas 
como mais adiante se mostrará é já o de hoje, um esperma que jorrando incondicionado é capaz de re-codificar o fixismo das inter-relações de parentesco, procriação e paternidade.

$\mathrm{Na}$ infância o sémen é higienizado (personificado que é por uma figura simpática e diligente, desvinculado da sua dimensão letal mas também do prazer), a um ponto que o quase torna irreconhecível para imaginário adulto onde já se efectivou a passagem, mediada pela cultura popular, da inocência e pureza à devassa. As dimensões do perigo ${ }^{28}$ e do prazer $^{29}$, "forcluídas" no imaginário infantil são presença constante em diversas narrativas sexuais patentes no espaço público.

A fetichização do sémen enquanto substância mágica e acme do erótico, está patente na própria evolução da filmografia pornográfica, sendo destacada por Moore, dado o seu carácter ilustrativo, a prática do bukkake (p. 74). Esta encenação da humilhação ritual vigente na cultura japonesa (reconhecidamente uma das mais sexistas do mundo), consiste em expor a mulher à ejaculação de sémen de vários homens. De acordo com Moore, independentemente das variações, o crucial é que o sémen esteja presente em grande quantidade, signo que é o garante da realização sexual plena (no cruzamento do plano técnico meramente repetitivo e infalível que caracteriza uma tarefa banal quotidiana e do imaginário da masculinidade nostálgica). Assim «mesmo que estes homens [os espectadores] não beneficiem directamente das relações hierárquicas do poder masculino, eles auxiliam filmes que caracterizam a dominação masculina na medida em que se identificam com o protagonista macho.» (p. 91) Aquilo que é distintamente indicado no momento da ejaculação é o restabelecer da lei depois da agitação motora (p. 78), lei que tem de ser repetitivamente reiterada por intermédio de «actos de superioridade e inferioridade, rituais e humilhação e fontes de dominação e submissão» (p. 79). Deste modo se perpetuam ao nível do imaginário, a hegemonia e a subjugação. Moore assinala que não é simples acaso a similitude entre as técnicas de filmagem dos desportos de massas e as cenas porno. $\mathrm{Na}$ sua produção massiva ambas as indústrias recorrem à múltipla perspectiva e ao slow motion (p. 80) no seu esgotamento simbólico do real pelo qual é deflagrada toda a riqueza ontológica do evento.

\footnotetext{
28 Presentificada massivamente na publicidade institucional e comercial ao preservativo (Moore, 2007, p. 72).

${ }^{29}$ Que Moore, de um modo exacerbado, identifica com o que na gíria porno se baptizou de "money shot". Cindy Patton assinalou como é na ejaculação, enquanto figuração do prazer masculino, que se assinala o encerramento da narrativa sexual. Cf. Idem (1989), "Hegemony and Orgasm - or the Instability of Heterosexual Pornography", Screen, vol. 30, no. 1-2, Winter/Spring 1989.
} 
As representações ingénuas do esperma prevalecem e persistem mesmo num momento em que as DST são ameaça real e a masculinidade perdeu as suas referências tradicionais. Como um Deus de marionetas, o realizador inserido no mainstream da indústria pornográfica deve saber quais os acordes capazes de agitar a fantasia colectiva do "homem médio". De modo a poder ultrapassar aquilo que é uma simples actividade mecânica, no vazio de um completo "desvelamento" fisiológico está dependente do suporte imaginário perverso. Apresenta o lugar onde o indivíduo castrado na ordem simbólica, procura o ideal, seduzido a ocupar abruptamente o lugar do desejo do Outro.

Por outro lado, a pornografia, ao acentuar a crueza do sémen (indicativo de uma verdade, essência natural do masculino que se trata de celebrar) no paroxismo que constitui erotização da ingestão seminal, é capaz de capitalizar o risco de uma ameaça propalada pela sensibilização institucional para as DST, mediatização e encenação da criminologia forense e pelas próprias empresas de fertilidade (vede infra). Ainda na indústria pornográfica mas já no exterior do sua "mercadoria fetichizada", a ameaça real do contágio manteve-se bem presente nas últimas três décadas. Mas, devido à sua maior vulnerabilidade, o sobreaviso face ao espectral grotesco do HIV e das DST, adquiriu um valor capital sobretudo entre os profissionais da prostituição. Aqui assinala Moore que, paradoxalmente, o carácter letal dos fluidos sexuais levou não somente a uma maior organização do negócio mas também ao surgimento de uma nova sensibilidade erótica. Motivados pelo propósito de evitar riscos de contágio os trabalhadores do sexo necessitaram de consciencializar os seus clientes e recorrer a diversos dispositivos de látex, o que conduziu a novas possibilidades de criatividade (pp. 86-88) ${ }^{30}$.

Também na Criminologia Forense os fluidos corporais, em especial o seminal, constituem referência crucial, permitindo ler as alterações nas expectativas relativas à masculinidade e relações de género. Vimos já a respeito do sistema de saúde tendências para validar formas de exclusão e segregação por via de referências às secreções inerentes à reprodução feminina. De acordo com tais ficções a menstruação e a gravidez remetem para uma incontinência que necessita de ser contida por intermédio de

${ }^{30}$ Cf. Moore, L. J. (1997), “'”It's Like You Use Pots and Pans to Cook. It's the Tool”: The Technologies of Safer Sex." Science, Technology, \& Human Values, vol. 22, no. 4, Autumn 1997, pp. 434-471. Este tema constituiu também o objecto de estudo da tese de doutoramento de Lisa Jean Moore intitulada "Producing Safer Sex: Knowledge, Latex Technologies, and Sex Workers in the Age of AIDS" apresentada em 1996 ao Departamento de Ciências Sociais e Comportamentais da UCSF, apresentação disponível em: < $\underline{\text { http:// }}$ www.managingdesire.org/Moore.html> (acedido a 24 de Abril de 2008). 
mecanismos regulatórios que respondem à necessidade de proteger a ordem social, confinando a mulher à esfera privada onde a sua identidade, contígua aos processos biológicos, pode ser estabilizada ${ }^{31}$. O facto de que na investigação criminal, para efeitos de prova judicial, o sémen é uma substância frequentemente decisiva para deliberar quanto à culpa ou à inocência dos indivíduos, coloca-nos agora perante a incontinência do próprio homem, também ele emissor de fluxos que não controla.

Moore faz um apanhado geral da história das ciências forenses, acompanhando o papel de destaque que o sémen desempenhou nestas desde o início do séc. XIX (pp. 127-30). O carácter distinto do sémen foi alvo de considerações na teoria criminal muito antes da revolução que constituiu a possibilidade de processar e analisar amostras de sémen em busca de vestígios de DNA. Salientavam-se sobretudo as suas propriedades bioquímicas que o tornam dúctil e fluído mas também capaz de entrar e sair dos corpos, de se impregnar em superfícies diversas originando nódoas com extrema resiliência, e finalmente a capacidade de preservar DNA. Inicialmente imerso numa aura de mistério e sacralidade que apenas remetia para o anónimo, a caracterização forense do sémen conduziu à sua progressiva desmistificação que tornou possível tomá-lo como substância única pertencente a um sujeito e como indício que permite a reconstituição de cenas criminais. Desta forma, «os motivos e "natureza" essencial dos homens são agora reconhecíveis pelos seus fluidos corporais.» (p. 145) Mas esta mesma "objectivação" do sémen não ficou isenta de consequências perniciosas. Acercando-se da biopolítica de Foucault, L. J. Moore centra-se em especial na forma como se implementou uma base de dados genéticos que cruza informações provindas de todos os estados norteamericanos $^{32}$. Moore reconhece este instrumento de vigilância como uma mais valia para o sistema criminal, mas a sua normativização do saber, ao estabelecer o socialmente desejável (normal, o criminoso e o insano),

${ }^{31}$ Partindo da impossibilidade, resultante dos avanços na Biomedicina, de delimitar os domínios do corpo e do sujeito, Margrit Shildrick promove também uma resignificação da dita "fluidez" [leakiness] feminina onde: «A indeterminação das fronteiras do corpo desafia a dicotomia entre si-mesmo e outro, deslocando a certeza ontológica e ameaçando minar as bases em que o si-mesmo pode estabelecer controlo» Idem (1997, Leaky Bodies and Boundaries: Feminism, Postmodernism and (Bio)ethics, London: Routledge, p 34. Neste sentido ver também Brook, B. (1999), Feminist Perspectives on the Body, London: Longman.

32 Trata-se da CODIS que agrega todos os perfis de DNA envolvidos em ocorrências criminais e informação da identidade correspondente, indivíduo determinado ou incógnito. Esta base de dados começou por funcionar ao nível local estendendo-se posteriormente ao nível federal (p. 122). 
continua a tratar o sémen de acordo com as diferentes ordens de poder vigentes (pp. 123-125). A autorização federal da recolha de amostras de DNA e características biológicas prévia ao perpetrar de delitos é ilustrativa da validação no sistema judicial de estereótipos relativos a género, classe social e etnia. Justificada a pretexto da promoção da prevenção e antecipação de delitos, esta medida incidiu sobretudo em grupos e indivíduos marginalizados, deixando o sistema vulnerável a perversões de diversa ordem (pp. 145-46). Moore nota como a selectividade determinativa de quem deve constar das ditas bases de dados «reflecte representações hegemónicas de noções de sexo e crime masculino» (p. 151), desde logo na representação do controlo sobre o sémen como protector da mulher, elemento invariavelmente frágil e vulnerável e que o sistema deve tratar de proteger, mantendo simultânemente tabu a defesa dos homens.

Longe das debilidades inerentes ao sistema criminal, vem-se assistindo à popularização e proliferação de séries televisivas onde a investigação criminal é encenada de modo ultrarealista. Ao analisar os argumentos de diferentes episódios deste tipo de séries Moore constata aqui a recorrência do tropo da antropomorfização do esperma, mas também da condenação moral de práticas sexuais tidas por desviantes (pp. 138-40). Por outro lado, a presença constante do sémen como elemento de prova originou nestas séries a expectativa de sentenças indubitáveis baseadas em factos objectivos. Moore refere como esta sobrevalorização da "testemunha silenciosa" pode conduzir a um perigoso descrédito da Justiça interpretativa. Tal tendência tem sido partilhada nos últimos anos pelos meios de comunicação social e público em geral e de acordo com a autora o sistema de justiça não lhe terá sido imune ${ }^{33}$. A este respeito diz a socióloga que «talvez a certeza moral do DNA não derive apenas de encontrar o perpetrador correcto, mas da predominante reprodução do género, sexualidade e ideologias raciais.» (p. 146) Uma outra consequência deste imediatismo crescente foi o surgir de um nicho de mercado de que se valeram várias empresas que, explorando as inseguranças de espectadores, vendem kits para análise de DNA e muitos outros artigos que permitem levar a cabo investigações privadas quanto à vida do seu parceiro (pp. 141-44).

Regressemos, depois deste roteiro pelas representações do sémen, ao ponto de origem das considerações tecidas por Moore: as técnicas reprodutivas e as possibilidades que estas abrem a novas formas de organização da intimidade.

${ }^{33}$ Fenómeno que entre os círculos da criminologia veio a ficar conhecido como CSI effect (p. 133). 
Estima-se que entre os 4 milhões de crianças nascidas anualmente nos EUA, cerca de 30000 sejam concebidas por intermédio de doação de esperma (p. 93). A manipulação e comercialização do esperma são claramente transgressivas dos ideais tradicionais de reprodução biológica e social. Moore refere que é usual entre a comunidade lésbica a cedência de frascos de esperma que não foram utilizados, uma vez que o tratamento foi suspenso por uma aplicação bem sucedida, ou seja, culminou na concepção (p. 105) $)^{34}$. O homem é reduzido a frasco de esperma anónimo chegando-se a uma estranha, mas sem dúvida significativa, inversão do pressuposto basilar que Lévi-Strauss expôs em As Estruturas Elementares do Parentesco de acordo com o qual "na sociedade humana apenas os homens trocam as mulheres, não o contrário". De acordo com Moore há também uma inversão na relação entre os pólos do natural e da racionalidade, a histeria e irracionalidade tradicionalmente caracterizadoras da mulher que é necessário cingir ao interior da esfera familiar, são transferidas para o homem: «as mulheres podem agora utilizar a tecnologia racional para os seus próprios fins extraindo o esperma do corpo macho sendo que, pelo menos alguns homens, parecem ser os histéricos, reclamando não serem mais necessários» (p. 120). Esta alteração das vias de acesso tradicional ao esperma ${ }^{35}$ gera debates incontornáveis quanto ao seu significado, uso e posse.

Vivendo na proximidade do epicentro daquele que viria a ser designado como lesbian baby boom ${ }^{36}$ (p. 4), Moore participou, enquanto profissional e mãe, das possibilidades abertas pela expansão dos "bancos de esperma". A longa presença nos bastidores destas organizações dá a esta socióloga as credenciais necessárias para avançar com uma densa crónica

34 A este respeito ver p.ex. a reportagem do New York Times: "First Comes the Baby Carriage" (publicada em 13 de Outubro 2005), disponível em: <http://www.nytimes.com/ 2005/10/13/fashion/thursdaystyles/13BANKS.html> acedido em: 26 de Abril de 2008.

35 Nesta sua ênfase Moore leva em conta que, contrastante com esta agitação "espermática", o comércio de oócitos é bastante reduzido uma vez que a sua recolha envolve consideráveis riscos para a saúde da dadora (p. 103).

${ }^{36}$ Este, mas também o chamado "gay baby boom" ocorrido ao longo da última década não se restringe apenas à obtenção da custódia legal dos filhos resultantes de um primeiro casamento, mas decorre precisamente da abertura progressiva, ao abrigo de alterações à legislação de determinados estados, de novas possibilidades de adopção e do recurso às técnicas de PMA por parte de casais homossexuais. Não há actualmente estatísticas relativas à difusão da parentalidade homossexual nos EUA o que explica a disparidade das estimativas que vão sendo avançadas. A este respeito cf. e.g. Johnson, S. M., \& O'Connor, E. (2002). The gay baby boom: The psychology of gay parenthood. New York: New York University Press. 
da comercialização de gâmetas onde se evidencia como os progressos da ciência e a vontade individual, subjacentes à constituição de formas alternativas de parentesco, tomaram sempre a dianteira face ao enquadramento e regulamentação legais, bem como às directivas políticas ${ }^{37}$. A tentativa de regulamentação de práticas comerciais de recolha, tratamento e troca de esperma, ocorreu ex post facto, sendo que a promoção da autoregulação deu por vezes azo a abusos.

É em meados dos anos 90 que se intensificam na sociedade civil dos EUA (ainda que com fortes laços ao sistema político) vários movimentos, cujo propósito é a promoção da família heterossexual tradicional e seu modelo parental. Entre estas organizações a mais destacada e mediatizada foi a FMR (Fatherhood Responsibility Movement) a qual, segundo Moore não constituiu excepção à tentativa conjunta de manipulação da opinião pública americana, recorrendo continuamente a argumentos infundados que apresentavam o declínio da função parental como sendo o ponto de origem de um vasto inventário de problemas domésticos, educacionais e sociais (pp. 112-114). Num breve excurso histórico podemos compreender o quando e o porquê das tentativas de barrar a instituição de mecanismos de reconhecimento de formas alternativas de género e intimidade. O século XIX constituiu um dos períodos mais reveladores quanto ao que caracteriza a ansiedade misógina que deverá servir também para compreender a mentalidade homofóbica. Ela tende a intensificar-se sempre que se perspectivam possibilidades de acréscimo de direitos das mulheres e leva à difusão de panfletos políticos, tratados religiosos e médicos que aludem invariavelmente a uma natureza das coisas, cultural e normativamente ratificada, que nas novas práticas sociais vê a sua pretensa regularidade pervertida ${ }^{38}$. A este impulso possibilitado em grande medida pela Industrialização, seguiu-se no século XX um longo desfile de conquistas emancipatórias, dentre as quais são de destacar além do direito ao voto e do crescente papel no mercado de trabalho, as técnicas contraceptivas, a interrupção voluntária da gravidez, o acesso às tecnologias reprodutivas e por fim a maternidade solteira voluntária ${ }^{39}$. Tem-se vindo a apontar de

${ }^{37}$ Nos Estados Unidos só em 2003 é que a FDA (Food and Drug Administration) veio unificar a acreditação de Bancos de esperma e a regulação dos seus produtos até então sob a intendência de duas organizações privadas: a cooperativa AATB (American Association of Tissue Banks) e a AFS (American Fertility Society), as quais foram responsáveis pela implementação de medidas para combater a propagação da SIDA em 1990 (p. 98).

${ }^{38}$ Cf. e.g. Kimmel, M. S. (1987), "Men's Responses to Feminism at the Turn of the Century" Gender and Society, vol 1, no. 3, September 1987, 261-283.

${ }^{39} \mathrm{Em}$ defesa do direito de optar por uma maternidade consciente surgiram organizações como a "Single Mothers by Choice" fundada em 1981: < http://singlemothersbychoice.com> 
forma frequentemente simplista que o contraponto claro deste quadro potenciador da capacidade de autodeterminação das mulheres é a erosão da auto-estima e bem-estar dos homens. Reflexo da misandria feminista, estes ter-se-iam visto excluídos da família, sem oportunidades para se realizar enquanto maridos e pais. Esta linha de argumentação é seguida entre outros por Lionel Tiger ao alertar para o perigo que representa para a espécie humana a transição entre uma sexualidade, que de acordo com este antropólogo tinha por fim a reprodução e paternidade, e técnicas contraceptivas e reprodutivas que quebram a sabedoria evolutiva ${ }^{40}$. Mas nas pressões neo-conservadoras que pretendem a restrição da aquisição de esperma por parte de mulheres lésbicas ou solteiras, Moore lê não uma defesa dos homens desejosos de ser pais, mas sim a tentativa derradeira de impedir a constituição de famílias autónomas à margem da família tradicional fundada em torno do par heterossexual e descendência biológica resultante da união. Dando como exemplo a exportação de esperma à escala global por parte da empresa dinamarquesa Cryos ${ }^{41}$, a socióloga revela como o carácter inflexível da vontade individual prevalece sobre imposições retrógradas e facilmente contornáveis: «com redes de distribuição ao longo dos continentes, o sémen viaja ao longo de super-autoestradas de informação e reprodução.» (p. 103).

Mas ao apostar em sistemas de avaliação crescentemente detalhados que permitem o mensurar exaustivo do esperma de diferentes homens, os bancos de esperma recapitulam a imago nostálgica da masculinidade, englobando também construções hierárquicas e hegemónicas. Moore alude ao singular caso do "Repository for Germinal Choise", a história deste mediático Banco de Esperma, é bem reveladora da complexidade e competitividade envolvidas na indústria do esperma. Tendo por mote «prevenir a degradação genética e inflectir a produção de humanos retrógrados» (pp. 8-9), esta instituição que seleccionava para dadores somente laureados com o Nobel ou indivíduos com distintas capacidades intelectuais, manteve-se em funcionamento durante quase duas décadas, mas devido à perda de popularidade face a outros Bancos viria a encerrar em 1999. De modo a alargar a sua quota de mercado aliciando também casais heterossexuais férteis estas empresas tiveram de conseguir inculcar a crença de que o tratamento de limpeza e a manipulação técnica do esperma que fornecem, constituem efectivamente uma mais valia. Dada a complexidade

${ }^{40}$ Cf. Idem (2000) The Decline of Males: The First Look at an Unexpected New World for Men and Women, New York: St. Martin's Press.

${ }^{41}$ Anuncia os seus serviços de distribuição de esperma e produtos relacionados para mais de 60 países: <www.cryosinternational.com/home.aspx> 
técnica envolvida nos processos de selecção, tratamento, preservação e aplicação, a que o "sémen natural" é submetido, estamos perante o que Moore denomina por "tecnosémen" (p. 107). Em contraponto claro à narrativa pornográfica, o sémen natural é aqui rejeitado como sujo e imprevisível, isto apesar de até ao momento não estar provado que o sémen tecnomodificado seja melhor que o "incorporado" [embodied] (p. 109).

Passando em revista os catálogos por meio dos quais estas empresas publicitavam o seu produto (numa fase prévia à difusão do acesso à Internet e estando ainda sujeitas a regulação débil) Moore deparava-se, também aqui, com a antropomorfização do esperma. Entre os gâmetas e o dador são estabelecidas correlações estritas quanto ao carácter e à personalidade naquilo que é uma revalidação com fins publicitários da teoria lamarckiana quanto à transmissão de características adquiridas (p. 111). «O esperma pode estar desincorporado, mas eles [dadores] são vivamente personificados como dóceis, saudáveis, ágeis, férteis e socialmente desejáveis.» (p. 100). Lembrando os anúncios pessoais dos classificados, o eventual comprador é convidado a escolher entre características fenotípicas: etnicidade, altura, peso, cabelo, compleição, mas também entre profissão, interesses e actividades sociais. Mas mesmo havendo segmentação do mercado permitindo dar resposta às preferências específicas de cada cliente, há sempre préselecções que limitam as possibilidades de escolha selectiva dos futuros pais antecipando a exclusão por parte destes de certas características genéticas, fenotípicas e psíco-sociais. Em 2005, adensando a lista de homens excluídos na reprodução intermediada por bancos de Esperma, a FDA, responsável pela acreditação e regulação dos procedimentos relativos à manipulação e tratamento biotecnológico de esperma, adoptou, sem qualquer fundamentação científica, novas regras que visam restringir a admissão de "sémen gay"(p. 102).

Os bancos de esperma contribuíram decisivamente para um reposicionamento das noções de masculinidade e paternidade uma vez que, na sua expansão económica, deixaram o papel simbólico do homem fora do processo reprodutivo. Mas ao mesmo tempo, diz-nos Moore, também estes «reforçam o número de ideais masculinos hegemónicos excluindo terminantemente certos homens e o seu esperma.» Ao dispor os homens de acordo com o seu poder físico e social «tanto as mulheres como os bancos de sémen estão a reproduzir as relações de género existentes.» (p. 119).

No trabalho de 2002 sobre a saúde, as autoras não se detiveram sobre os condicionalismos no recurso aos tratamento da infertilidade com a profundidade requerida ${ }^{42}$, mas será na questão do acesso à PMA que

42 A abordagem da infertilidade dentro da epidemiologia social é apenas passageira, Cf. Lorber \& Moore, 2002: 22-4. 
podemos captar na sua acepção mais pura a construção social da doença. Para tal precisamos de retirar todas as consequências decorrentes da forma peremptória como a OMS qualificou a infertilidade como doença e preconizou a necessidade de providenciar acesso generalizado ao seu tratamento. Se a realização reprodutiva é parte integrante da saúde do indivíduo, como, quando e com base em que critérios, pode ser barrado por interposição de norma, o acesso a este cuidado de saúde? Dentro da comunidade médica é consensual apontar como causa desta doença, além de factores hereditários e incógnitos, diversas variáveis ambientais. As recentes evoluções nas técnicas reprodutivas e a constatação empírica do recurso por parte de um número significativo de mulheres à compra e troca de gâmetas masculinos, mas também o recurso a procriação substitutiva por parte de homens e mulheres, colocam-nos perante a impossibilidade de uma definição da infertilidade que recorra a uma "natureza das coisas", que não esteja já à partida dependente de uma compreensão da cultura, traduzida em condicionalismos de ordem social e política. Perante o conceito clínico de "infertilidade" 43 um filósofo, evitando a todo o custo um desnecessário torcionar dos limites da terminologia, enfrenta sérias dificuldades uma vez que aquele conceito mantém uma referência biológica inoperante no simbólico. Para a sua compreensão da forma como as sociedades codificam o acesso à reprodução, será mais apropriada a terminologia "invertida" dos demógrafos ao distinguir entre fecundidade (potencialidade para procriar) e fertilidade (produção efectiva de crianças).

Se por um lado «o esperma é um instrumento que pode desconstruir relações de género tradicionais e permitir o emergir de novos tipos familiares», persistem diversos poderes instituídos que «controlam o significado do esperma de modo bastante conservador» (p. 148). Mas é a própria liquefacção do sémen, decaído das suas diferentes hipostases e resignificado na sua objectivação, que mediando entre o ideal e o material, o persistente e o corruptível, pode conduzir a uma libertação das hierarquias de género e sexualidade. As características bioquímicas caracterizadoras do esperma, conferindo-lhe as propriedades da fluidez e da fixação nas mais variadas superfícies, são figuras que aludem à profunda "incrustação" significante desta substância na ordem da consciência. Dadas as diferentes representações de que é alvo, o sémen é signo capaz de transmitir a validade de visões conservadoras de homem e mulher e de

43 «Infertility is defined as the inability to achieve conception after 1 year of regular, unprotected intercourse.» "Female Infertility and Assisted Reproductive Technology" in Legato M. J. (ed.), Principles of Gender-Specific Medicine vol. 1, San Diego: Elsevier Academic Press, 2004, 550-564, p. 550. 
estruturas familiares regressivas, mas também do potencial libertador de uma natureza sempre reinventada. Extraído das condutas exíguas e mistificadas pelas quais era conduzido à solidificação reproduzindo as possibilidades de inteligibilidade cultural, fora da norma da reprodução heterossexual, o sémen perturba a solidez da ordem conceptual da reprodução, da família e da identidade de género. Imiscuindo-se no articulável da cadeia dos significantes ou nódulo em que confluem os medos relativos à tecnologia e à demografia, o sémen torna visíveis lugares que permaneciam à margem da representatividade política ${ }^{44}$.

${ }^{44}$ Sou devedor aqui das considerações de Judith Butler relativamente ao debate sobre a legitimação estatal do parentesco homossexual Cf. e.g. Idem (2002) "Is Kinship Always Already Heterosexual?" A Journal of Feminist Cultural Studies, vol. 13, no. 1, Spring 2002, pp. 14-44, artigo em que a filósofa retoma o tema do processo de "literalização" da fantasia por via do desejo do desejo do Estado, capaz no seu reconhecimento de ratificar as práticas sexuais e reprodutivas como permanentes. 